\title{
EFEK PENGGUNAAN KONSENTRAT PABRIKAN DAN BUATAN SENDIRI DALAM RANSUM BABI STARTER TERHADAP EFISIENSI PENGGUNAAN RANSUM
}

\author{
S.N. Rumerung* \\ Fakultas Peternakan Universitas Sam Ratulangi Manado, 95115
}

\begin{abstract}
ABSTRAK
Penelitian ini dilakukan untuk mengetahui perbandingan efisiensi penggunaan ransum babi starter yang mengkonsumsi konsentrat pabrikan dan buatan sendiri. Penelitian ini menggunakan 20 ekor babi jantan kastrasi dan ditempatkan dalam 20 unit kandang individu. Rancangan penelitian yang digunakan adalah Rancangan Acak Kelompok (RAK), terdiri dari 4 perlakuan dan 5 kelompok. Perlakuan terdiri dari R1 (konsentrat Pokphan 32\% + jagung 50\% dan dedak 18\%), R2 (konsentrat Benfeed 32\% + jagung 505 dan dedak 18\%), R3 (konsentrat Cargill 32\% + jagung 50\% dan dedak 18\%), R4 (konsentrat buatan sendiri $32 \%+$ jagung $50 \%$ dan dedak $18 \%$ ). Variabel yang diukur adalah konsumsi ransum, pertambahan berat badan dan efisiensi penggunaan ransum. Hasil analisis keragaman menunjukkan bahwa perlakuan memberikan pengaruh yang berbeda tidak nyata $(\mathrm{P}>0,05)$ terhadap konsumsi ransum, pertambahan berat badan dan efisiensi penggunaan ransum. Berdasarkan hasil tersebut dapat disimpulkam bahwa ternak babi fase starter memberikan respons efisiensi penggunaan ransum yang sama baiknya terhadap konsentrat buatan sendiri dan konsentrat pabrikan dalam ransum.
\end{abstract}

Kata kunci: konsentrat pabrikan, konsentrat buatan sendiri, babi starter.

\section{ABSTRACT}

\begin{tabular}{|c|c|}
\hline EFFECT & UTILIZATION \\
\hline COMMERCIAL & LOCA \\
\hline ENTRATE & DIETS ON \\
\hline
\end{tabular}

present study was conducted to determine the comparison of feed efficiency of starter pigs consumed local and commercial concentrate diets. Twenty castrated male pigs were allocated in individual crate. Experimental design used in the present study was completely randomized design (CRD) with four treatments and five replications. Treatments were arranged as follows: $\mathrm{R} 1=$ Pokphan's concentrate diet $32 \%+$ yellow corn $50 \%+$ rice bran $18 \%$; R2 $=$ Benfeed's concentrate diet $32 \%$ + yellow corn $50 \%+$ rice bran 18\%; R3= Cargill's concentrate diet 32\% + yellow corn $50 \%$ + rice bran 18\%; R4= Local's concentrate diet $32 \%+$ yellow corn $50 \%+$ rice bran $18 \%$. Variables measured were daily feed consumption, daily gain, and feed efficiency. Research results showed that treatments gave no significant effect on daily feed consumption, daily gain and feed efficiency. It can be concluded that starter pigs gave a similar respons when either local concentrate or commercial concentrate diets.

Keywords: commercial concentrate, local concentrate, starter pig

\section{PENDAHULUAN}

Pemenuhan kebutuhan pangan untuk perbaikan gizi masyarakat merupakan program nasional yang ingin dicapai dan salah satunya adalah bidang peternakan yang diarahkan pada

\footnotetext{
* Jurusan Nutrisi dan Makanan Ternak
} 
peningkatan populasi serta produksi ternak termasuk ternak babi. Ransum merupakan faktor terbesar (sekitar 60-70\%) dalam meningkatkan produksi ternak babi sehingga peningkatan ketersediaan bahan baku pakan dan penurunan biaya ransum perlu dilakukan guna meningkatkan produksi peternakan.

Saat ini usaha budidaya ternak babi terkendala dengan tingginya harga bahan baku pakan karena kebanyakan masih diimpor dan sering kompetitif dengan kebutuhan manusia sehingga ketersediaannya tidak berkesinambungan. Ketika musim kemarau panjang, peternak sering mengalami kelangkaan bahan pakan (konsentrat pabrikan) dan pada saat-saat tertentu bahan pakan ini sempat menghilang dari pasaran, kalaupun ada harganya relative mahal. Kondisi tersebut menggambarkan pola usaha peternakan babi di Sulawesi Utara tidak sustainable karena hanya tergantung pada suplai bahan pakan pabrikan saja, akibatnya banyak peternak babi yang terpaksa berhenti dari usahanya.

Konsentrat adalah campuran beberapa bahan pakan yang disusun untuk membuat suatu ransum komplit serta zatzat makanannya seimbang. Umumnya peternak menggunakan konsentrat yang dicampur dengan jagung kuning dan dedak halus. Guna menanggulangi masalah mahalnya konsentrat pabrikan, peternak dapat membuat konsentrat sendiri dengan menggunakan bahan-bahan pakan seperti tepung ikan, bungkil kelapa dan bungkil kedele.

Berdasarkan uraian di atas maka telah dilakukan suatu penelitian yang bertujuan untuk melihat pengaruh penggunaan konsentrat pabrikan dan buatan sendiri dalam ransum babi starter terhadap efisiensi penggunaan ransum.

\section{MATERI DAN METODE PENELITIAN}

Penelitian ini menggunakan 20 ekor babi jantan kastrasi ras local berumur 1,5 sampai 2,3 bulan dengan berat badan awal $8-19 \mathrm{~kg}$. Keduapuluh ekor babi tersebut dibagi menjadi 5 kelompok yaitu : kelompok 1 (berat badan awal $9 \pm 1 \mathrm{~kg}$ ), kelompok 2 (berat badan awal $12 \pm 1 \mathrm{~kg}$ ), kelompok 3 (berat badan awal $15 \pm 1 \mathrm{~kg}$ ), kelompok 4 (berat badan awal $18 \pm 1 \mathrm{~kg}$ ) dan kelompok 5 (berat badan awal $21 \pm 1$ $\mathrm{kg}$ ). Masing-masing kelompok terdiri atas 1 ekor babi dan mendapat 4 macam ransum sebagai perlakuan. Ransum percobaannya (Tabel 3) terdiri atas : R1 (ransum dengan konsentrat merk Pokphan = A), R2 (ransum dengan konsentrat merk Benfeed = B), R3 (ransum dengan konsentrat merk Cargill = C) dan R4 (ransum dengan konsentrat buatan sendiri). 
Kandang yang digunakan pada penelitian ini adalah kandang individu sebanyak 20 unit yang masing-masing berukuran panjang $1,5 \mathrm{~m}$, lebar $1,0 \mathrm{~m}$ dan tinggi 1,0 m. Lantai dan dinding kandang terbuat dari beton, masing-masing kandang dilengkapi dengan tempat pakan serta air minum yang terbuat dari beton dengan ukuran $30 \times 30 \times 30 \mathrm{~cm}$. Peralatan yang digunakan antara lain : timbangan kapasitas $25 \mathrm{~kg}$ (untuk menimbang ransum), timbangan merk standard (untuk menimbang ternak percobaan), sekop, ember, selang air dan lain-lain.

Bahan-bahan pakan yang digunakan sebagai penyusun ransum adalah jagung kuning, dedak halus, konsentrat pabrikan dan konsentrat buatan sendiri seperti tercantum pada Tabel 1. Bahan-bahan pakan yang digunakan untuk menyusun konsentrat buatan sendiri adalah tepung ikan, tepung kedele dan bungkil kelapa dapat dilihat pada Tabel 2.

Tabel 1. Bahan-Bahan Pakan Penyusun Ransum Penelitian dan Kandungan Nutriennya

\begin{tabular}{lcccccc}
\hline \multicolumn{1}{c}{ Bahan Pakan/ } & \multicolumn{7}{c}{ Kandungan Nutrien } \\
\cline { 2 - 7 } \multicolumn{1}{c}{ Konsentrat } & $\begin{array}{c}\text { Protein } \\
\end{array}$ & $\begin{array}{c}\text { Lemak } \\
(\%)\end{array}$ & $\begin{array}{c}\text { Serat Kasar } \\
(\%)\end{array}$ & $\begin{array}{c}\mathrm{Ca} \\
(\%)\end{array}$ & $\begin{array}{c}\mathrm{P} \\
(\%)\end{array}$ & $\begin{array}{c}\mathrm{EM} \\
(\mathrm{kkal} / \mathrm{kg})\end{array}$ \\
\hline Jagung kuning*) & 9,81 & 4,90 & 2,78 & 0,01 & 0,33 & 3241,60 \\
Dedak halus & 11,62 & 10,10 & 12,72 & 0,02 & 0,72 & 3187,20 \\
Merk A**) & 38,00 & 4,00 & 6,00 & 3,00 & 1,40 & 3650,00 \\
Merk B**) & 38,00 & 5,00 & 5,00 & 4,50 & 1,40 & 3600,00 \\
Merk C**) & 37,50 & 3,00 & 6,00 & 3,90 & 1,30 & 3600,00 \\
Buatan sendiri*) & 38,25 & 10,64 & 15,65 & 4,26 & 2,36 & 3714,08 \\
\hline
\end{tabular}

*) Berdasarkan hasil analisis laboratorium Kimia Unsrat Manado, 2013.

**) Berdasarkan label zat-zat makanan dari pabrik.

Tabel 2. Bahan-Bahan Pakan Penyusun Konsentrat Buatan Sendiri dan Kandungan Nutriennya

\begin{tabular}{lcccccc}
\hline Bahan Pakan & \multicolumn{5}{c}{ Kandungan Nutrien*) } \\
\cline { 2 - 7 } & $\begin{array}{c}\text { Protein } \\
(\%)\end{array}$ & $\begin{array}{c}\text { Lemak } \\
(\%)\end{array}$ & $\begin{array}{c}\text { Serat Kasar } \\
(\%)\end{array}$ & $\begin{array}{c}\text { Ca } \\
(\%)\end{array}$ & $\begin{array}{c}\text { P } \\
(\%)\end{array}$ & $\begin{array}{c}\text { EM } \\
(\mathrm{kkal} / \mathrm{kg})\end{array}$ \\
\hline Tepung ikan (30\%) & 50,80 & 6,61 & 1,06 & 3,06 & 0,85 & 3887,68 \\
Bungkil kedele (42\%) & 40,90 & 13,20 & 21,06 & 0,19 & 0,54 & 3756,96 \\
Bungkil kelapa (28\%) & 20,50 & 12,35 & 26,35 & 10,42 & 6,26 & 3461,52 \\
\hline
\end{tabular}

*) Hasil Analisis Laboratorium Kimia Unsrat Manado, 2013. 
Tabel 3. Komposisi Ransum Perlakuan dan Kandungan Nutriennya

\begin{tabular}{|c|c|c|c|c|}
\hline \multirow{2}{*}{$\begin{array}{l}\text { Bahan Pakan/ } \\
\text { Konsentrat }\end{array}$} & \multicolumn{4}{|c|}{ Perlakuan } \\
\hline & $\mathrm{R} 1$ & $\mathrm{R} 2$ & R3 & $\mathrm{R} 4$ \\
\hline & & & & $\ldots$ \\
\hline Jagung kuning & 50 & 50 & 50 & 50 \\
\hline Dedak halus & 18 & 18 & 18 & 18 \\
\hline Konsentrat & 32 & 32 & 32 & 32 \\
\hline Total & 100 & 100 & 100 & 100 \\
\hline \multicolumn{5}{|l|}{ Kandungan nutrien $*)$} \\
\hline Protein $(\%)$ & 19,16 & 19,16 & 18,99 & 19,23 \\
\hline Lemak $(\%)$ & 5,55 & 5,87 & 5,23 & 7,67 \\
\hline Serak Kasar (\%) & 5,60 & 5,28 & 5,60 & 8,69 \\
\hline $\mathrm{Ca}(\%)$ & 0,97 & 1,45 & 1,42 & 1,37 \\
\hline $\mathrm{P}(\%)$ & 0,74 & 0,74 & 0,90 & 1,05 \\
\hline Energi Metabolis (kkal/kg) & 3280,00 & 3050,00 & 3050,00 & 3383,10 \\
\hline
\end{tabular}

*) Hasil perhitungan berdasarkan data Tabel 1 dan 2.

\section{Tatalaksana Penelitian}

Kandang dan semua peralatan yang akan digunakan selama penelitian dibersihkan dahulu sebelum penelitian dimulai. Kandang difumigasi dahulu sebelum ternak percobaan ditempatkan kedalamnya dan semua ternak percobaan deberi obat cacing untuk membebaskan ternak babi dari pengaruh cacing dan parasite usus, kemudian dilanjutkan dengan memberikan obat diare.

Tahap awal penelitian dilakukan adaptasi pakan selama 1 minggu, hal ini bertujuan agar ternak mengkonsumsi pakan perlakuan dan membiasakan ternak terhadap lingkungan. Setelah masa adaptasi dilakukan pengambilan data konsumsi ransum dan pertambahan berat badan selama 60 hari. Konsumsi ransum dan air minum diberikan secara ad libitum setiap hari dimulai pukul 07.00 pagi. Ransum penelitian yang diberikan selama 1 hari dan sisa ransum keesokan harinya ditimbang selama periode pengumpulan data. Setiap minggu ternak percobaan ditimbang untuk mendapatkan bobot badan awal dan akhir penelitian.

\section{Variabel yang diukur dan cara menentukannya :}

1. Konsumsi ransum dihitung dengan mengurangi jumlah ransum yang diberikan dengan sisa ransum selama 24 jam (Parakkasi, 1990).

2. Pertambahan berat badan (PBB)

Penimbangan babi penelitian dilakukan dua minggu sekali

$\mathrm{PBB}=\frac{\text { Berat akhir }(\mathrm{Kg})-\text { Berat awal }(\mathrm{Kg})}{\text { Jarak Penimbangan (hari ) }}$ 
3. Efisiensi penggunaan ransum dihitung dari perbandingan rata-rata pertambahan berat

(gr) dengan rata-rata konsumsi ransum (gr) per ekor per hari.

\section{Rancangan Penelitian}

Rancangan penelitian yang digunakan adalah Rancangan Acak Kelompok (RAK) yang terdiri dari 4 macam ransum sebagai perlakuan dan 5 kelompok sebagai ulangan. Data hasil penelitian dianalisis keragamannya sesuai rancangan penelitian yang digunakan, apabila terdapat pengaruh yang berbeda nyata antar perlakuan maka dilanjutkan dengan uji BNJ (Beda Nyata Jujur) (Steel and Torrie, 1991).

\section{HASIL DAN PEMBAHASAN}

\section{Pengaruh Perlakuan Terhadap Konsumsi Ransum}

Data hasil perhitungan rataan konsumsi ransum dari masing-masing perlakuan yang diberikan selama penelitian tercantum pada Tabel 4. Rataan konsumsi ransum ternak babi selama penelitian berkisar antara 1504,92 gr 1637,57 gr. Kisaran konsumsi ransum tersebut masih berada dalam standar kebutuhan yang direkomendasikan oleh NRC (1998) yaitu rata-rata konsumsi ransum per ekor per hari untuk ternak babi dengan berat badan sekitar $15-47,5 \mathrm{~kg}$ adalah $1250-2500 \mathrm{gr}$.

Hasil analisis keragaman menunjukkan bahwa babi yang mengkonsumsi konsentrat pabrikan dan buatan sendiri memberikan pengaruh yang berbeda tidak nyata $(\mathrm{P}>0,05)$ terhadap konsumsi ransum. Hal ini berarti masingmasing perlakuan memberikan respons yang sama. Ransum penelitian memiliki kandungan protein dan energi yang hampir sama sehingga dapat dimengerti masingmasing ransum perlakuan memberikan pengaruh yang berbeda tidak nyata terhadap konsumsi ransum. Menurut

Tabel 4. Rataan efisiensi penggunaan ransum per ekor per hari per perlakuan (gram).

\begin{tabular}{lcccc}
\hline \multirow{2}{*}{ Variabel } & \multicolumn{4}{c}{ Perlakuan } \\
\cline { 2 - 5 } & $\mathrm{R} 1$ & $\mathrm{R} 2$ & $\mathrm{R} 3$ & $\mathrm{R} 4$ \\
\hline Konsumsi $(\mathrm{gr})^{\mathrm{ns}}$ & 1504,92 & 1569,39 & 1591,35 & 1637,57 \\
\hline PBB $(\mathrm{gr}){ }^{\mathrm{ns}}$ & 530 & 532 & 556 & 574 \\
\hline Efisiensi Penggunaan Ransum $(\mathrm{gr})^{\mathrm{ns}}$ & 0,346 & 0,334 & 0,340 & 0,346 \\
\hline
\end{tabular}


Sihombing (2006) jumlah konsumsi ransum sangat dipengaruhi oleh tingkat protein dan energi ransum. Kandungan protein dan energi yang sama dalam ransum akan menghasilkan jumlah konsumsi ransum yang tidak berbeda.

\section{Pengaruh Perlakuan Terhadap Pertambahan Berat Badan}

Hasil pengamatan pertambahan berat badan ternak babi penelitian per ekor per hari selama penelitian tercantum dapat dilihat pada Tabel 4. Rataan pertambahan berat badan babi penelitian berkisar antara 530 gr sampai 574 gr. Hasil penelitian ini masih sesuai dengan yang direkomendasikan oleh NRC (1998) yaitu pertambahan berat badan ternak babi dengan berat badan sekitar $10 \mathrm{~kg}$ sampai $60 \mathrm{~kg}$ berkisar $500 \mathrm{gr}$ sampai $750 \mathrm{gr}$.

$\begin{array}{ccr}\text { Hasil } & \text { analisis } & \text { keragaman } \\ \text { memperlihatkan } & \text { bahwa } & \text { perlakuan }\end{array}$
memberikan pengaruh yang berbeda tidak nyata $(\mathrm{P}>0,05)$ terhadap pertambahan berat badan ternak percobaan. Perbedaan yang tidak nyata dari masing-masing perlakuan tersebut disebabkan oleh jumlah konsumsi dan kualitas (zat-zat makanan) dari keempat macam ransum yang hampir sama.

\section{Pengaruh Perlakuan Terhadap Efisiensi Penggunaan Ransum}

Rataan efisiensi penggunaan ransum per ekor per hari untuk empat macam ransum penelitian sebagai perlakuan disajikan pada Tabel 4. Efisiensi penggunaan ransum ternak percobaan berkisar antara 0,33 sampai 0,35. Angka ini masih sesuai standar efisiensi ransum yang direkomendasikan oleh NRC (1998) yaitu untuk ternak babi dengan berat badan sekitar 10 sampai $60 \quad \mathrm{~kg}$ efisiensi penggunaan ransumnya berkisar 0,264 sampai 0,368 .

Hasil analisis keragaman memperlihatkan bahwa perlakuan memberikan pengaruh yang berbeda tidak nyata $(\mathrm{P}>0,05)$ terhadap efisiensi penggunaan ransum. Ini berarti keempat macam ransum perlakuan memberikan respons yang sama terhadap efisiensi penggunaan ransum. Tidak adanya perbedaan efisiensi penggunaan ransum pada penelitian ini disebabkan oleh jumlah konsumsi ransum dan pertambahan berat badan (sebagai ukuruan efisiensi ransum) ternak percobaan yang hampir sama. Hal ini disebabkan karena komposisi zat-zat makan ransum percobaan hampir sama. Menurut Wahyu (!992) efisiensi penggunaan ransum dipengaruhi oleh konsumsi ransum, daya cerna dan penggunaan zat-zat makanan. 
Berdasarkan hasil analisis tersebut dapat ditarik kesimpulan bahwa ransum yang menggunakan konsentrat pabrikan dan konsentrat buatan sendiri memberikan efek yang tidak berbeda terhadap efisiensi penggunaan ransum.

\section{KESIMPULAN}

Hasil penelitian ini menunjukkan bahwa ternak babi fase starter memberikan respons yang sama baiknya terhadap konsentrat pabrikan dan konsentrat buatan sendiri dalam ransum.

\section{DAFTAR PUSTAKA}

NRC, 1998. Nutrient Requirements of Swine. $10^{\text {th }}$ Resived Ed. The National Academies

Press.

Parakkasi, A., 1990. Ilmu Gizi dan Makanan Ternak Monogastrik. Penerbit Yasaguna, Bandung.
Sihombing, D.T.H., 2006. Ilmu Ternak Babi. Cetakan Kedua. Gadjah Mada University Press. Yogyakarta.

Steel, R.G.D dan J.H. Torrie., 1991. Prinsip dan Prosedur Statistika. Suatu Pendekatan Biometrik. Edisi Kedua. Penerjemah Bambang Sumantri. PT. Gramedia Pustaka Utama. Jakarta.

Wahyu, J., 1992. Ilmu Nutrisi Unggas. Gadjah Mada University Press. Yogyakarta. 